\title{
Chem. Biodiversity
}

\section{Isolation and antimacrofouling activity of indole and furoquinoline alkaloids from'guatambú'trees (Aspidosperma australe and Balfourodendron riedelianum)}

\author{
Miriam Pérez $z^{\mathrm{a}, \mathrm{b}}$, Cristian M. Pis Diez ${ }^{\mathrm{c}, \mathrm{d}}$, María Belén Valdez ${ }^{\mathrm{c}, \mathrm{d}}$, Mónica García ${ }^{\mathrm{a}}$, Analía \\ Paola $^{a, b}$, Esteban Avigliano ${ }^{e, f}$, Jorge A. Palermo ${ }^{c, d}$, Guillermo Blustein ${ }^{\star a, g}$
}

a Centro de Investigación y Desarrollo en Tecnología de Pinturas- CIDEPINT, Calle52 e/ 121 y 122- La Plata B1900AYB, Argentina.

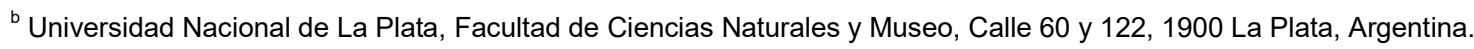

${ }^{c}$ Universidad de Buenos Aires, Departamento de Química Orgánica - Facultad de Ciencias Exactas y Naturales, Ciudad Universitaria, Pabellón 2 - (1428) - Buenos Aires - Argentina.

${ }^{d}$ CONICET-Universidad de Buenos Aires, Unidad de Microanálisis y Métodos Físicos en Química Orgánica (UMYMFOR), Buenos Aires, Argentina.

e Instituto de Investigaciones en Producción Animal (INPA-CONICET-UBA), Av. Chorroarín 280 (C1427CWO), Universidad de Buenos Aires, Buenos Aires, Argentina.

${ }^{\mathrm{f} C e n t r o ~ d e ~ I n v e s t i g a c i o n e s ~ A n t o n i a ~ R a m o s ~(C I A R), ~ F u n d a c i o ́ n ~ B o s q u e s ~ N a t i v o s ~ A r g e n t i n o s . ~ C a m i n o ~ B a l n e a r i o ~}$ $\mathrm{s} / \mathrm{n}$, Villa Bonita, Misiones, Argentina.

'Universidad Nacional de La Plata, Facultad de Ciencias Agrarias y Forestales, Calle 60 y 119, 1900 La Plata, Argentina. e-mail: g.blustein@cidepint.ing.unlp.edu.ar

\begin{abstract}
In this work the antifouling activity was studied of five alkaloids isolated from trees of the Atlantic rainforest. The tested alkaloids were: olivacine (1), uleine (2) and $N$-methyltetrahydroellipticine (3) from Aspidosperma australe ('yellow guatambú') and the furoquinoline alkaloids kokusaginine (4) and flindersiamine (5) from Balfourodendron riedelianum ('white guatambú'). All these compounds can be isolated from their natural sources in high yields in a sustainable way. The five compounds were subjected to laboratory tests (attachment test of the mussel Mytilus edulis platensis) and field trials, by incorporation into soluble matrix paints, and 45 days of exposure of the painted panels in the sea. The results show that compound $\mathbf{3}$ is a very potent antifoulant, and that compounds $\mathbf{4}$ and $\mathbf{5}$ are also very active, while compounds $\mathbf{1}$ and $\mathbf{2}$ did not show any significant antifouling activity. These results open the way for the development of environmentally friendly antifouling agents, based on abundant and easy-topurify compounds that can be obtained in a sustainable way.
\end{abstract}

Keywords: $N$-methytetrahydroellipticine $\bullet$ antifouling $\bullet$ kokusaginine $\bullet$ flindersiamine $\bullet$ indole alkaloids

\section{Introduction}

The Atlantic rainforest, a widely diverse ecosysten shared mainly by Brazil, Argentina and Paraguay has largely disappeared, mostly deforested for timber production, soybean and sugar-cane plantations, or for cattle farming. In northeastern Argentina, the province of Misiones still preserves the southernmost portion of this ecosystem. A non-governmental organization, "Fundación Bosques Nativos Argentinos para la Biodiversidad" (Argentine Native Forests for Biodiversity Foundation) has launched a project to reforest with native species partially degraded areas, and to support scientific research as a way to protect 


\section{Chem. Biodiversity}

this ecosystem. ${ }^{[1]}$ The preservation strategy is dynamic, with focus on a sustainable use of natural resources and the generation of scientific knowledge, as a way to gain political and financial support and the involvement of the local population for preservation projects. In this respect, the discovery of alternative uses for abundant and easily-isolable natural products from native trees is one of the goals of the project. In this work is explored the potential use as marine antifoulants of some abundant alkaloids that can be isolated from two native species: Aspidosperma australe (yellow guatambú) and Balfourodendron riedelianum (white guatambú). Although both species share the trivial name guatambú, they belong to different families, and this is refected in their secondary metaboites. $A$. australe belongs to the family Apocynaceae and produces indole alkaloids, while $B$. riedelianum is a Rutaceae and produces furoquinoline alkaloids.

Marine fouling organisms, such as barnacles, mussels, hydroids, and ascidians cause serious problems by settling on ship hulls, and other water-borne structures such as hydroelectric power plants, cooling systems, off-shore platforms and fishing equipment. ${ }^{[2-4]}$ Biofouling represents a major nuisance for maritime industries, especially for shipping, as biofouling on ship hulls may increase boat weight, subsequently inducing over-consumption of fuel and increased maintenance costs. ${ }^{[5]}$ To protect these marine structures from such settlement, paints containing biocidal compounds such as organotin and copper compounds have been widely used as the most effective antifouling agents. ${ }^{[6]}$ However, numerous reports of environmental contamination have brought the use of these metal-based compounds, especially organotin derivatives, to be restricted or even banned. ${ }^{[7]}$ Therefore, environmentally benign alternatives are urgently required.

Marine benthic organisms are constantly exposed to colonization by other organisms such as bacterial communities and invertebrate larvae. Some of these organisms have developed various strategies to counteract the settlement of fouling organisms, such as the production of antifouling chemicals and/or physical defenses ${ }^{[8]} \mathrm{A}$ variety of natural products with antifouling activity have been isolated from marine organisms, including marine bacteria, algae, seagrasses, and marine invertebrates. ${ }^{[9-10]}$ However, these metabolites are typically isolated in low yields from delicate and slow-growing marine organisms which cannot be harvested in a commercial scale without environmental harm. ${ }^{[11]}$ All these issues expose an almost unsolvable sustainability problem for the large-scale production of natural antifoulants of marine origin. As a consequence, the search of natural antifoulants from more sustainable resources is a main challenge. In this sense, abundant and easy collectable terrestrial plants represent a promising alternative. ${ }^{[12-14]}$ Terrestrial plants produce secondary metabolites that exhibit a variety of biological activities, and there are reports of the use of plant extracts as antifoulants. ${ }^{[15-16]}$ Some plant bioactive compounds have shown antifouling properties in previous studies. ${ }^{[17-26]}$ In this work is studied the antifouling activity of five alkaloids: three indole alkaloids from the bark of $A$. australe and two furoquinoline alkaloids from the bark of $B$. riedelianum, by laboratory and field assays. These compounds, which have been known for several decades, fulfill the following criteria used for sample selection: previous reports of biological activity for compounds of the same family, high yields of extraction from their biological sources, and simple purification protocols. The laboratory experiments included attachment tests with the mussel Mytilus edulis platensis. The alkaloids were then tested in the field by inclusion in experimental soluble-matrix paints, which were then assayed in the sea.

\section{Results and Discussion}




\section{Chem. Biodiversity}

The bark extract of $A$. australe produced three major known alkaloids: the pyridocarbazole olivacine (1), and the indole alkaloids uleine (2) and $N$-methyltetrahydroellipticine (3), while the bark of $B$. riedelianum yielded two major known furoquinoline alkaloids: kokusaginine (4) and flindersiamine (5) (Scheme 1).<smiles>Cc1nccc2c(C)c3[nH]c4ccccc4c3cc12</smiles>

$1(800 \mathrm{mg} / \mathrm{kg}$ bark $)$<smiles>C=C1Nc2ccccc2C2CC3CCC(C12)N3C</smiles>

$2(1,2 \mathrm{~g} / \mathrm{kg}$ bark $)$<smiles>Cc1c2c(c(C)c3c1[nH]c1ccccc13)CN(C)CC2</smiles>

$3(400 \mathrm{mg} / \mathrm{kg}$ bark)<smiles>COc1cc2nc3occc3c(OC)c2cc1OC</smiles>

$4(400 \mathrm{mg} / \mathrm{kg}$ bark)<smiles>COc1c2c(cc3c(OC)c4c(cc13)OCO4)OCO2</smiles>

5 (590 $\mathrm{mg} / \mathrm{kg}$ bark)

Scheme 1. Alkaloids studied in this work with their typical isolation yields: olivacine (1), uleine (2), $N$-methyltetrahydroellipticine (3), kokusaginine (4) and flindersiamine (5)

The five alkaloids were subjected to laboratory and field trials for antifouling activity. For the laboratory experiments, $M$. edulis platensis was the chosen organism, because it is one of the most conspicuous components of the fouling community of Mar del Plata harbor (location of the tests), and settles on both artificial and natural surfaces. The bioassays with this organism have the advantages of being fast, reproducible, and that they can be performed in a small scale. ${ }^{[27]}$ These mussels are commonly used in laboratory protocols to detect antifouling compounds, and are conveniently obtained by scraping from rocks and also easy to maintain under laboratory conditions.

The five compounds were first tested in an attachment assay. In this test, the mussels are exposed to different concentrations of the alkaloids, the number of settled and unsettled mussels is counted after $24 \mathrm{~h}$., and the $\mathrm{EC}_{50}$ (effective concentration at which fifty percent of mussels showed inhibition of attachment) is then calculated. The $\mathrm{EC}_{50}$ values are shown in Table 1.

Table 1. Effective concentration to avoid $50 \%$ settlement $\left(E C_{50}\right)$ of the tested alkaloids

\begin{tabular}{lc}
\hline Alkaloid & $\mathrm{EC}_{50}\left(\mathbf{n m o l} / \mathrm{cm}^{2}\right)$ \\
\hline Olivacine (1) & 7.59 \\
Uleine (2) & 9.95 \\
N-methyltetrahydroellipticene (3) & 1.78 \\
Kokusaginine (4) & 3.86 \\
Flindersiamine (5) & 5.56 \\
\hline
\end{tabular}

These results showed marked differences between the tested alkaloids. Two of the compounds, $N$-methyltetrahydroellipticine (3) and kokusaginine (4), yielded the best results in this experiment. Compound $\mathbf{3}$ affected mussel settlement at concentrations as low as $0.87 \mathrm{nmol} / \mathrm{cm}^{2}$ and reached a settlement inhibition of $50 \%$ at $1.78 \mathrm{nmol} / \mathrm{cm}^{2}$, while compound 4 started to affect the settlement at $1.81 \mathrm{nmol} / \mathrm{cm}^{2}$ and had an $\mathrm{EC}_{50}$ of $3.86 \mathrm{nmol} / \mathrm{cm}^{2}$. Comparatively, olivacine (1) and flindersiamine (5) were less effective, while uleine (2), showed no significant antifouling activity.

For the field tests, the five alkaloids were then incorporated individually into soluble-matrix paints. Paints were applied on acrylic tiles; the coated tiles were then set on aluminium racks and tested in the ocean for 45 days. Tiles coated with paint without the addition of alkaloids and unpainted acrylic tiles were also included as controls. The results obtained after 45 days of exposure are shown in Figure 1. 


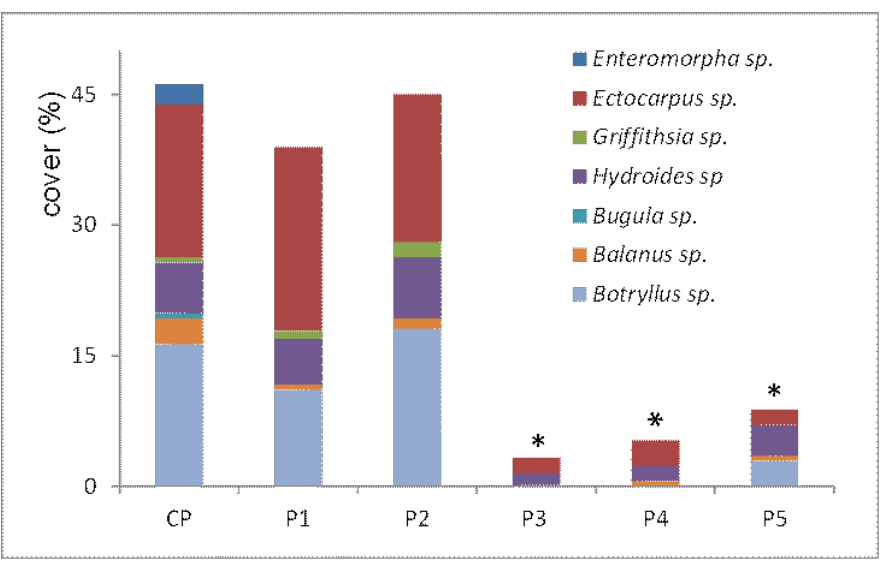

Figure 1.Fouling cover percentage for each paint composition, 45 days exposure. 1: olivacine; 2: uleine.; 3: $N$ methyltetrahydroellipticine; 4: kokusaginine; 5: flindersiamine; CP: control paint; ${ }^{*}$ ) significant differences, $p<0.05$.

As expected, a strong recruitment of fouling organisms was observed in the non-painted acrylic panels. In contrast, the panels coated with antifouling paints containing flindersiamine (5), kokusaginine (4) and $\mathrm{N}$-methyltetrahydroellipticine (3) tested at Mar del Plata harbour after 45 days, showed significant differences in cover percentages $(p<0.05)$. On the other hand, paints with olivacine (1) and uleine (2) showed no significant antifouling activity. The paints with compounds $\mathbf{3}$ and $\mathbf{4}$ showed the best performances, and the results of the field experiments agreed with previous laboratory observations. These paints completely inhibited the settlement of the green alga Ulva intestinalis, the red alga Griffithsia sp. and colonial species such as the bryozoan Bugula sp. and the tunicate Botryllus sp. At the same time, a marked decrease was observed in the settlement of the calcareous tubeworm Hydroides sp., the crustacean Balanus sp. and the brown alga Ectocarpus sp. The results with compound 3 were slightly better than with compound 4 . However, there are not significant differences between them $(p=0.284)$. Compound $\mathbf{5}$ showed also a good antifouling profile, however, it did not inhibit completely the settlement of Botryllus sp, and did not affect greatly Hydroides sp.

There is a trend in the field of marine natural products to associate antifouling activity with cytotoxicity, a theory which is reinforced by the fact that a large number of marine secondary metabolites, which where crafted by nature to provide marine organisms with chemical weapons to face ecological challenges such as biofouling, also show cytotoxic activity. ${ }^{[2]}$ However, the reverse argument, that is that cytotoxic terrestrial natural products may also display antifouling activity in the marine environment, is not necessarily true. This is evidenced by the results of the present work, in which olivacine (1), a compound of known cytotoxic activity, ${ }^{[29]}$ was a very poor antifoulant. Biofouling is a complex process that develops through different stages, and this means that several other mechanisms of action, besides toxicity, may result in an antifouling effect. Kokusaginine (4) and flindersiamine (5) are furoquinoline alkaloids, and there are previous reports of antifouling compounds that have a furan ring. ${ }^{[23,30-33]}$ In particular, kokusaginine has several reported biological activities: acetylcholinesterase inhibition, ${ }^{[34-35]}$ insect antifeedant activity, ${ }^{[36]}$ antitumor, ${ }^{[37]}$ antiparasitic, ${ }^{[38-39]}$ and antibiotic. ${ }^{[40]}$ These last two biological activities may be directly related to the antifouling effect. On the other hand, there are only a few references on the bioactivity of $N$-methyltetrahydroellipticine (3), the most active compound of the test. Ellipticine (a biosynthetic relative of 3 ) received much attention in recent times due to its potent antitumor activity, which led to several studies on its mode of action (which is in part due to its planar structure with high DNA intercalating capacity) and the development of synthetic methodologies which led to the preparation of numerous derivatives, some of which reached clinical trials as anticancer drugs. ${ }^{[41]}$ However compound $\mathbf{3}$ is not cytotoxic (maybe due to 


\section{Chem. Biodiversity}

the loss of planarity in ring D), so probably its antifouling action arises from another, yet undisclosed, mechanism of action. ${ }^{[42]}$ In all the experiments some settlement of the algae Ectocarpus sp. and tubeworm Hydroides sp. was observed, and this indicates that it may be necessary to adjust the content of active compound or to combine these compounds with other biocides for a more effective formulation.

This is the first report of antifouling activity for furoquinoline or tetrahydropyridocarbazole alkaloids. As always in the case of natural antifouling compounds with a possible industrial use, there is the question of ecological sustainability and supply. All these alkaloids were isolated in fairly large amounts (typically $0.4-1 \mathrm{~g}$ of alkaloid from $1 \mathrm{~kg}$ of bark). Stripping $1 \mathrm{~kg}$ of bark from trees which are more than $20 \mathrm{~m}$ high, and have trunks more than $60 \mathrm{~cm}$ wide, leaves just a small mark which is healed in a few months without further damage to the tree. So, it can be concluded that the compounds tested in this work can be obtained in a sustainable way, without ecological damage. These results are the first step towards the development of an effective antifouling coating. Since there are reported syntheses of compound $\mathbf{3}$, the cost/benefit of the synthetic or extractive obtention of this substance will eventually have to be considered. ${ }^{[43]}$ In this respect, the intense reforestation programs which are carried on in the province of Misiones may ensure a continuous and sustainable supply of compound $\mathbf{3}$.

\section{Conclusions}

In this work, five alkaloids (three indole alkaloids and two furoquinoline alkaloids) were tested for antifouling activity in laboratory and field trials. All these compounds can be easily isolated in large amounts in a sustainable way from the barks of two species (A. australe and B. riedlianum) of the Atlantic rainforest. The indole alkaloid $N$-methyltetrahydroelipticine (3) was the most active antifoulant, while the furoquinoline alkaloids kokusaginine (4) and flindersiamine (5) were also very active. Taking into account that the structural differences in compounds $\mathbf{4}$ and $\mathbf{5}$ translated into different antifouling potencies, the furoquinoline core becomes an interesting scaffold for further research on the structure-activity relationships of these compounds in the search for more active antifoulants. As for compound $\mathbf{3}$, this is a new and interesting result for a compound which received little attention in terms of its biological activity, especially taking into account its lack of cytotoxicity. In this respect, the possible use of compounds $\mathbf{3}$ or $\mathbf{4}$ as environmentally friendly antifoulants may add value to the natural resources of the Atlantic rainforest, and help to gain support for ongoing preservation and reforestation strategies.

\section{Experimental Section}

\section{General}

All the solvents used for chromatography were distilled from glass. NMR spectra were recorded on the following instruments: Bruker AC-200 (200.13 MHz), Fourier 300 (300 MHz) and Bruker Avance III (500.13 MHz) spectrometers. In all cases, the internal reference was the signal of residual non deuterated solvent. TLC analyses were carried out on Merck Sílicagel 60 F254 plates and column chromatography was performed on Merck Silicagel (230-400 mesh). Sephadex LH-20 was obtained from GE-Healthcare. TLC plates were observed under UV light $(254 \mathrm{~nm})$ or sprayed with $2 \%$ vainillin in concentrated $\mathrm{H}_{2} \mathrm{SO}_{4}$. 


\section{Chem. Biodiversity}

\section{Extraction and Purification}

The barks of $A$. australe (yellow guatambú, $800 \mathrm{~g}$ ) and B. riedelianum (white guatambú, $1.5 \mathrm{~kg}$ ) were collected at C.I.A.R. (Centro de Investigaciones Antonia Ramos), Campo Ramón, Misiones; Argentina. In both cases the bark was cut into small pieces and then macerated in $\mathrm{EtOH}(1 \mathrm{~L} \mathrm{EtOH} / 1 \mathrm{~kg}$. bark) for 7 days at room temperature. The procedure was repeated twice, and the combined extracts were taken to dryness at reduced pressure. The isolation procedure was different for both species, and purification schemes are included in the Supplementary Material.

A. australe: The crude extract $(8 \mathrm{~g})$ was suspended in $300 \mathrm{~mL}$ of $10 \%$ aqueous $\mathrm{HCl}$ and then $300 \mathrm{~mL}$ of EtOAc were added. The aqueous acidic phase was extracted twice again with EtOAc $(200 \mathrm{~mL})$, and then neutralized with $20 \%$ aqueous $\mathrm{NaOH}$. The neutral aqueous phase was extracted three times with $300 \mathrm{~mL}$ of EtOAc, and the organic phase was taken to dryness to obtain the crude alkaloid extract $(3.5 \mathrm{~g})$. Permeation of this extract through a large Sephadex LH-20 column $(80 \times 4 \mathrm{~cm})$, and further separation by silica gel column chromatography (elution solvent: $\mathrm{CH}_{2} \mathrm{Cl}_{2}: \mathrm{MeOH} 9: 1$ ) yielded the indole alkaloids (in order of elution) uleine $(2,1.20 \mathrm{~g})$, olivacine $(1,800 \mathrm{mg})$, and $\mathrm{N}$-methyltetrahydroellipticine $(3,400 \mathrm{mg})$. The alkaloids were identified by

${ }^{1} \mathrm{H}$ and ${ }^{13} \mathrm{C}$ NMR spectroscopy and comparison with literature data. ${ }^{[44-45]}$

B. riedelianum: The crude extract ( $13 \mathrm{~g})$ was subjected to VLC on silica gel, taking $500 \mathrm{~mL}$ fractions, using a cyclohexane: EtOAc gradient with $10 \%$ increments, and finally washing with $\mathrm{MeOH}$. The fractions eluted with cyclohexane:

EtOAc (3:7) and (2:8) contained kokusaginine (4) and flindersiamine (5). Final purification of the alkaloids was obtained by column chromatography on silica gel using a $\mathrm{CH}_{2} \mathrm{Cl}_{2}$ / EtOAc gradient. In this way $400 \mathrm{mg}$ of pure compound 4 and $590 \mathrm{mg}$ of compound 5 were obtained. The alkaloids were identified by ${ }^{1} \mathrm{H}$ and ${ }^{13} \mathrm{C}$ NMR spectroscopy and comparison with literature data. ${ }^{[46-47]}$

\section{Biological Assays}

Tests for antifouling activity were conducted using mussels collected from intertidal rocks at Playa Chica (3808'17'S, 57³1'18' W, Mar del Plata, Argentina). In the laboratory, individuals were disaggregated and conditioned in artificial seawater (ASTM D1141/75), $\mathrm{pH} 8.2-8.3$, salinity $33-35 \%$, temperature $22 \pm 2^{\circ} \mathrm{C}$, with suitable aeration and natural light. Mussels were not fed and seawater was not changed during experiments.

Five dilutions of each alkaloid were prepared in its corresponding solvent, i.e., uleine and $\mathrm{N}$-methyltetrahydroellipticine were dissolved in dioxane, olivacine was dissolved in acetone, while flindersiamine and kokusaginine were solubilized in methanol. Final concentrations were $0.25 ; 0.125 ; 0.06 ; 0.03 ; 0.015 \mathrm{mg} / \mathrm{mL}$.

For the attachment assays, $5 \mathrm{~mL}$ of each dilution were pipetted and applied onto the bottom of $9 \mathrm{~cm}$ diameter Petri dishes, and the organic solvent was allowed to evaporate at room temperature for $24 \mathrm{~h}$. Controls were prepared in a similar way but applying only $5 \mathrm{~mL}$ of solvent. Mussel bioassays were performed following the modified method of Ina et al. ${ }^{[48]}$ This bioassay was conducted to evaluate the effect of different concentrations of 'guatambú' compounds on the production of byssal threads. In this context, five healthy mussels, M. edulis platensis, (1.0-1.5 cm length) were fixed by means of a twocomponent epoxy adhesive (Poxipol®) to each Petri dish.

The compounds were assayed over concentrations of $0.12 ; 0.23 ; 0.47 ; 0.98$ and $2 \mu \mathrm{g} / \mathrm{cm}^{2}$. Then, each dish was filled with artificial seawater and incubated in a culture chamber at $20^{\circ} \mathrm{C}$ for $24 \mathrm{~h}$ in darkness. After this period of time, byssal threads were stained with fuchsine to enhance counting and visualization. These experiments indicated the number of settled and not settled mussels at different concentrations of alkaloids after exposure. A mussel is considered 'settled' when it secreted at least one 


\section{Chem. Biodiversity}

byssus thread. The effective concentration at which fifty percent of mussels showed inhibition of attachment was determined as $E_{50}$. Three replicates were set up for each of the treatment groups and for controls.

\section{Formulation, manufacture and application of antifouling coatings}

For the preparation of soluble matrix antifouling paints, hydrogenated rosin and WW rosin were used as binders and oleic acid and polyterpene resin as plasticizers. Base paint (BP) was prepared by dissolution of resins and plasticizers in toluene using a high-speed disperser. Then, this mixture plus the pigments (zinc oxide and calcium carbonate) were loaded in a laboratoryscale ball mill and dispersed for $24 \mathrm{~h}$. BP was formulated with the following composition (as weight \%): hydrogenated rosin (14.9), WW rosin (12.5), oleic acid (3.8), polyterpene resin (2.3), zinc oxide (33.2), calcium carbonate (11.1). This paint was filtered and fractionated in seven portions, one of which was used as a negative control and the remaining as treatments. For treatments, each alkaloid was incorporated into BP at 250 ppm and dispersed during $1 \mathrm{~h}$. Paints were applied by brush on sandblasted acrylic tiles $\left(4 \times 10 \mathrm{~cm}^{2}\right)$ which were previously degreased with toluene. Four coats of paint were applied to achieve a final dry thickness of $100 \mu \mathrm{m}$.

\section{Field trials}

Coated panels were assembled on aluminum racks and submerged in a marina in Mar del Plata harbor (Argentina) for 45 days during summer season. In addition, paints without the addition of alkaloids and unpainted acrylic tiles were simultaneously submerged as controls. Cover percentages were estimated by the dot grid method that consists in the identification and frequency of settled organisms located at 25 random points. ${ }^{[49]}$ The methodology is carried out by exhaustive taxonomical identification under stereomicroscope (Leica Stereozoom S8 APO equipped with a DFC 295 digital camera and analytical software) and optical microscope. All tests were performed in triplicate.

\section{Statistical analysis}

The normality and homogeneity assumptions were verified by using Shapiro Wilk's and Levene's tests respectively $(p<0.05)$. The differences between treatments and control were determined by one-way analysis of variance (ANOVA) followed by Tukey post hoc test. All statistical analyses were performed with SPSS 22 software. Estimations of $\mathrm{EC}_{50}$ and reduction of fifty percent of byssal thread number were calculated through Probit analysis.

\section{Supplementary Material}

Supporting information (isolation schemes and NMR spectra) for this article is available on the WWW under http://dx.doi.org/10.1002/MS-number 


\section{Acknowledgements}

We are grateful to Dr. Nahuel Schenone, Mr. Javier Unizony and all the staff at the C.I.A.R. for their help during our field trips to Misiones. Research at UMYMFOR-FCEN-UBA was supported by grants from CONICET to JAP (PIP 2014-2016 Nº 11220130100523CO), UBA (UBACyT 2014-2017 № 20020130100457BA) and ANPCyT (PICT 2014-2063). GB, JAP and EA, are researchers of CONICET. CMPD and MBV thank CONICET for doctoral fellowships. MP, MG, AP and GB thank to UNLP, CONICET and CICPBA for their financial support. They also wish to thank the Club de Motonáutica of Mar del Plata for permission to use their marine testing site.

\section{Author Contribution Statement}

Miriam Pérez: Investigation, Methodology. Field trials and paint performance evaluation

Cristian Pis Diez and María Belén Valdez: extraction and purification of alkaloids

Mónica García: bioassays for antifouling activity and statistical analysis

Analia Paola: Field trials and paint performance evaluation

Esteban Avigliano: sample collection, organization of field trips and logistics

Jorge A. Palermo: Investigation, Methodology. Structural elucidation of alkaloids

Guillermo Blustein: Investigation, Methodology. Paint formulation, preparation and application. Field trials and logistics.

Miriam Pérez, Jorge Palermo and Guillermo Blustein wrote the manuscript.

\section{References}

[1] 'FundaciónBosquesNativosArgentinos para la Bioversidad' http://www.bosques.org.ar

[2] M. D. Richmond, R. Seed, 'A review of marine macrofouling communities with special reference to animal fouling', Biofouling 1991, 2, 151168.

[3] M. Leer-Andersen, L. Larsson, 'An experimental/numerical approach for evaluating skin friction on full-scale ships with surface roughness', J. Mar. Sci. Technol. 2003, 8, 26-36.

[4] M. P. Schultz, 'Effects of coating roughness and biofouling on ship resistance', Biofouling 2007, 23, 331-341.

[5] M. P. Schultz, J. Bendick, E. Holm, W. Hertel,'Economic impact of biofouling on a naval surface ship', Biofouling 2011, 27, 87-98.

[6] C. Hellio, D. Yebra, in 'Advances in marine antifouling coatings and technologies', Eds. C. Hellio and D. Yebra, CRC Press, Boca Raton, 2009, p.1.

[7] M. Costello, A. Grant, I. Davies, S. Cecchini, S: Papoutsoglou, D. Quigley, M. Saroglia, 'The control of chemicals used in aquaculture in Europe', J. Appl. Ichthyol. 2001, 17, 173-180.

[8] L. Tan, P. Goh, A. Tripathi, M. Lim, G. Dickinson, S. Lee, S. Teo, 'Natural antifoulants from the marine cyanobacterium Lyngbya majuscula', Biofouling 2010, 26, 685-695.

[9] N. Fusetani, 'Antifouling marine natural products', Nat. Prod. Rep. 2011, 28, 400-410.

[10] P.Y. Qian, S.Y. Xu, in: 'Handbook of marine natural products', Eds. E. Fattorusso, H. Gerwick, O. Taglialatela-Scafati, Springer Science, 2012, p. 749.

[11] D. Rittschof, in: 'Marine Chemical Ecology', Eds. J. B. McClintock, B. J. Baker, CRC Press, Boca Raton, 2001 , p. 543. 


\section{Chem. Biodiversity}

[12] M. Angarano, R. Mc Mahon, D. Hawkins, J. Schetz, 'Exploration of structure-antifouling relationships of capsaicin-like compounds that inhibit zebra mussel (Dreissena polymorpha) macrofouling', Biofouling 2007, 23, 295-305.

[13] M. Pérez, M- García, G. Blustein, M. Stupak, 'Tannin and tannate from the quebracho tree: an eco-friendly alternative for controlling marine biofouling', Biofouling 2007, 23, 151-159.

[14] G. Blustein, M. Pérez, M. García, M. Stupak, C. Cerruti, 'Reversible effect of potassium sorbate on Balanus amphitrite larvae. Potential use as antifoulant', Biofouling 2009, 25, 573-580.

[15] S. Sawant, S. Sonak, A. Garg, 'Growth inhibition of fouling bacteria and diatoms by extracts of terrestrial plant, Derris scandens (Dicotyledonae: Leguminosae)', Indian J. Mar. Sci. 1995, 24, 229-230.

[16] W. Lin, C. Lu, Y. Ye, 'Toxicity of crude extracts from several terrestrial plants to barnacle larvae on mangrove seedlings', Ecol. Eng. 2009, 35, 502-510.

[17] S. Hyodo, H. Etoh, N. Yamashita, K. Sakata, K. Ina, 'Structure of resinosides from Eucalyptus resinifera as repellents against the blue mussel, Mytilus edulis', Biosci. Biotechnol. Biochem. 1992, 56, 138.

[18] I. Singh, K. Takahashi, H. Etoh, 'Potent attachment-inhibiting and -promoting substances for the blue mussel, Mytilus edulis galloprovincialis, from two species of Eucalyptus', Biosci. Biotechnol. Biochem. 1996, 60, 1522-1523.

[19] H. Etoh, T. Kondoh, R. Noda, I. Singh, Y. Sekiwa, K. Morimitsu, K. Kubota, 'Shogaols from Zingiber officinale as promising antifouling agents', Biosci. Biotechnol. Biochem. 2002, 66, 1748-1750.

[20] Q. Xu, C. Barrios, T. Cutright, B. Newby, 'Evaluation of toxicity of capsaicin and zosteric acid and their potential application as antifoulants', Environ. Toxicol. 2005, 20, 467-474.

[21] J. Chen, D. Feng, Z. Yang, Z. Wang, Y. Qiu, Y. Lin, 'Antifouling metabolites from the mangrove plant Ceriops tagal', Molecules 2008, 13, 212-219.

[22] D. Feng, C. Ke, C. Lu, S. Li, 'Herbal plants as a promising source of natural antifoulants: evidence from barnacle settlement inhibition', Biofouling 2009, 25, 181-190.

[23] X. Zhou, Z. Zhang, Y. Xu, C. Jin, H. He, X. Hao, P. Qian, 'Flavone and isoflavone derivatives of terrestrial plants as larval settlement inhibitors of the barnacle Balanus amphitrite', Biofouling 2009, 25, 69-76.

[24] M. Pérez, M. García, M. Sánchez, M. Stupak, M. Mazzuca, J. Palermo, G. Blustein, 'Effect of secochiliolide acid isolated from the Patagonian shrub Nardophyllum bryoides as active component in antifouling paints', Int. Biodeter. Biodegr. 2014, 89, 37-44.

[25] M. Pérez, M. Sánchez, M. Stupak, M. García, M. T. Rojo de Almeida, M. T., J. C. Oberti, J. Palermo, G. Blustein, 'Antifouling activity of celastroids isolated from Maytenus species, natural and sustainable alternatives for marine coatings', Ind. Eng. Chem. Res. 2014, 53, 7655-7659

[26] L. Moodie, R. Trepos, G. Cervin, K. Brathen, B. Lindgard, R. Reiersen, P. Cahill, H. Pavia, C. Hellio, J. Svenson, 'Prevention of marine biofouling using the natural allelopathic compound batatasin-III and synthetic analogues', J. Nat. Prod. 2017, 80, 2001-2011.

[27] H-U. Dahms, C. Hellio, in 'Laboratory bioassays for screening marine antifouling compounds. Advances in marine antifouling coatings and technologies.' Eds. C. Hellio, D. Yebra, CRC Press, Boca Raton, 2009, p. 275.

[28] A. R. Carroll, B. R. Copp, R. A. Davis, R. A. Keyzers, Michèle R. Prinsep, 'Marine Natural Products', Nat. Prod. Rep. 2019, 36, 122-173, and previous reviews.

[29] E.S. Roesch, in 'Privileged Scaffolds in Medicinal Chemistry; Design, Synthesis, Evaluation', Ed. S. Bräse, RSC Drug Discovery Series No 50, Royal Society of Chemistry, London, 2016, p. 169.

[30] R. de Nys, M. Givskov, N. Kumar, S.Kjelleberg, P. Steinberg, 'Furanones', Prog.Mol. Subcell. Biol. 2006, 42, 55-86.

[31] S. Dobretsov, H. Dahms, H. YiLi, M. Wahl, P. Qian, 'The effect of quorum sensing blockers on the formation of marine microbial communities and larval attachment', FEMS Microbiol. Ecol. 2007, 60, 177-188.

[32] Y.Xu, H. He, S. Schulz, X. Liu, N.Fusetani, H. Xiong, X. Xiao, P. Qian, 'Potent antifouling compounds produced by marine Streptomyces' Bioresour. Technol. 2010,101, 1331-1336.

[33] Y. Li, H. Wu, Y. Xu, C. Shao, C. Wang, P. Qian, 'Antifouling activity of secondary metabolites isolated from Chinese Marine organisms' Mar Biotechnol 2013, 15, 552-558.

[34] E. M. Cardoso-Lopes, J. A. Maier, M R. da Silva, L. O. Regasini, S. Y. Simote, N. Peporine Lopes, J. R. Pirani, V. da Silva Bolzani , M. C. Marx Young, 'Alkaloids from stems of Esenbeckia leiocarpa Engl. (Rutaceae) as potential treatment for Alzheimer disease', Molecules 2010, 15, 9205-9213.

[35] V. Gómez-Calvario, M. A. Ramírez-Cisneros, M. Acevedo-Quiroz, M.Y. Rios, 'Chemical composition of Helietta parvifolia and its in vitro anticholinesterase activity', Nat. Prod. Res. 2019, 33, 889-892.

[36] T. Sackett, G. Towers, M. Isman, 'Effects of furoquinoline alkaloids on the growth and feeding of two polyphagous lepidopterans'. Chemoecol. 2007, 17, 97-101.

[37] J. Molnar, I. Ocsovszki, L. Puskas, T. Ghane, J. Hohmann, I. N. Zupko, 'Investigation of the antiproliferative action of the quinoline alkaloids kokusaginine and skimmianine on human cell lines', Curr. Signal Transd. T. 2013, 8, 148-155.

[38] J. D. Wansi, H. Hussain, A. T. Tcho, S. F. Kouam, S. Specht, S. R. Sarite, A. Hoerauf, K. Krohn, 'Antiplasmodial activities of furoquinoline alkaloids from Teclea afzelii', Phytother. Res. 2010, 24, 775-777.

[39] I. V. Ogungbe, J. D Ng, W. N. Setzer, 'Interactions of antiparasitic alkaloids with Leishmania protein targets: a molecular docking analysis', Future Med. Chem. 2013, 5, 1777-1799. 


\section{Chem. Biodiversity}

[40] T. S. Fernandes, D- Copetti, G. do Carmo, A. T. Neto, M. Pedroso, U. F. Silva, M. A. Mostardeiro, R. E. Burrow, I. I. Dalcol, A. F. Morel, 'Phytochemical analysis of bark from Helietta apiculata Benth and antimicrobial activities', Phytochemistry 2017, 141, 131-139.

[41] E.C. O'Sullivan, C.M. Miller, F.M. Deane, F.O. McCarthy, in 'Studies in Natural Products Chemistry 39', Ed: A.U. Rahman, Elsevier, Amsterdam, 2013, p. 189.

[42] A. Montoia, L. F. Rocha e Silva, Z. E. Torres, D. S. Costa, M. C. Henrique, E. S. Lima, M. C. Vasconcellos, R. C. Z. Souza, M. R. F. Costa, A. Grafov, I. Grafova, M. N. Eberlin, W. P. Tadei, R. C. N. Amorim, A. M. Pohlit, 'Antiplasmodial activity of synthetic ellipticine derivatives and an isolated analog', Bioorg. Med. Chem. Lett. 2014, 24, 2631-2634.

[43] R. Besselièvre, H.P. Husson, 'Syntheses in the ellipticine-olivacine series. A possible biogenetic model', Tetrahedron 1981, 37, 241-246.

[44] Z.E. Torres, E.R. Silveira, L.F. Rocha e Silva, E. S. Lima, M.C. de Vasconcellos, D.E. Uchoa, R. Braz Filho, A.M. Pohlit, 'Chemical composition of Aspidosperma ulei Markgr. and antiplasmodial activity of selected indole alkaloids', Molecules 2013, 18, 6281-6297.

[45] M.C. Henrique, S.M. Nunomura, A.M- Pohlit, 'Indole alkaloids from the bark of Aspidosperma vargassi and A. desmanthum', Quim. Nova 2010, 33, 284-287.

[46] H. Paulini, R. Waibel, O. Schimmer, 'Mutagenicity and structure-mutagenicity relationships of furoquinolines, naturally occurring alkaloids of the Rutaceae', Mutat. Res. 1989, 227, 179-186.

[47] J. Pusset, J.L. Lopez, M. Pais, M. Al Neirabeyeh, J.M. Veillon, 'Isolation and 2D NMR studies of alkaloids from Comptonella sessilfoliola', Planta Med. 1991, 57, 153-155.

[48] K. Ina, R. Takasawa, A. Yagi, N. Yamashita, H. Etoh, K. Sakata, 'An improved assay method for antifouling substances using the blue mussel, Mytilus edulis', Agric. Biol. Chem 1989, 53, 3319-3321.

[49] M.S. Foster, C. Harrold, D.D. Hardin, 'Point versus photo quadrat estimates of the cover sessile marine organisms', J. Exp. Mar. Biol. Ecol. 1991, 146, 193-203.

Entry for the Table of Contents

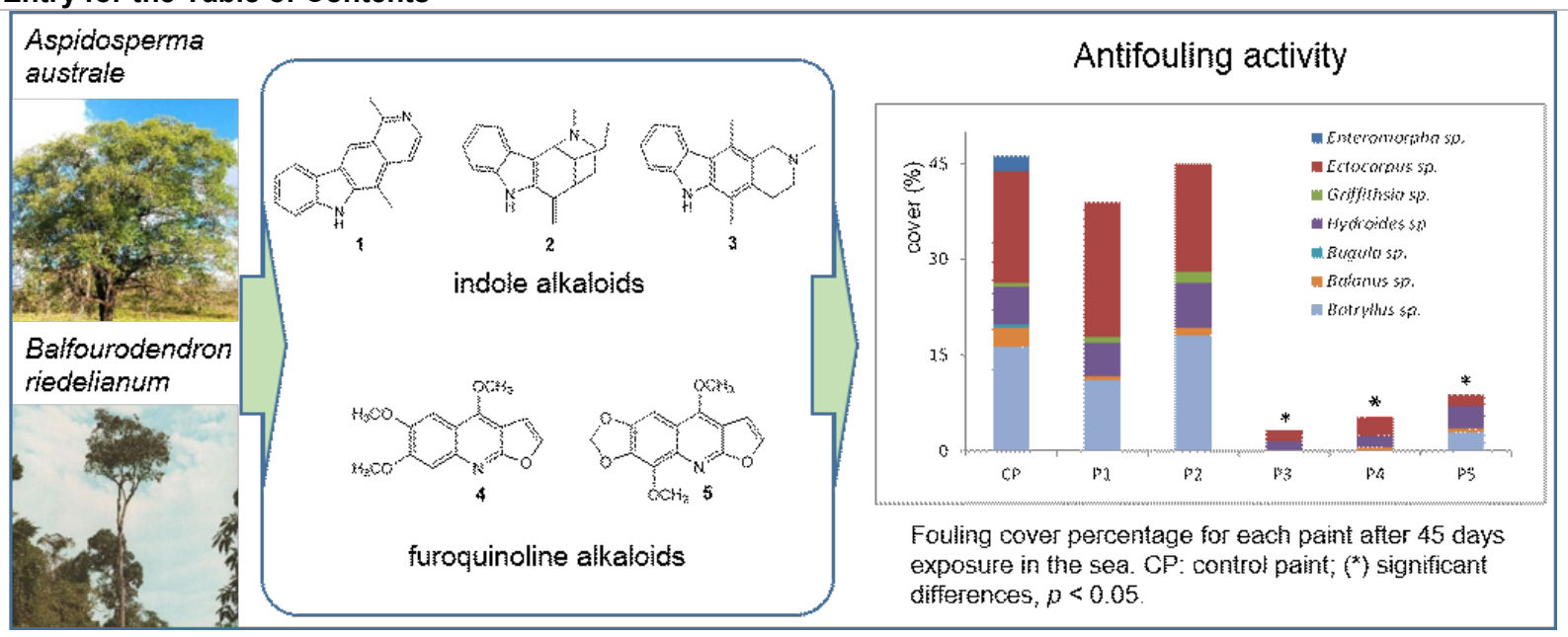

